Original Research Paper

\title{
Contamination of Nitrate in Groundwater and Evaluation of Health Risk in Bachok, Kelantan: A Cross-Sectional Study
}

\author{
${ }^{1}$ Aida Soraya Shamsuddin, ${ }^{1}$ Sharifah Norkhadijah Syed Ismail, \\ ${ }^{1}$ Emilia Zainal Abidin, ${ }^{1}$ Ho Yu Bin and ${ }^{2}$ Hafizan Juahir \\ ${ }^{I}$ Department of Environmental and Occupational Health, Faculty of Medicine and Health Sciences, \\ Universiti Putra Malaysia (UPM), 43400 Serdang, Selangor, Malaysia \\ ${ }^{2}$ East Coast Environmental Research Institute (ESERI), Universiti Sultan Zainal Abidin (UniSZA), \\ Gong Badak Campus, 21300 Kuala Terengganu, Terengganu, Malaysia
}

\author{
Article history \\ Received: 28-10-2015 \\ Revised: $16-01-2016$ \\ Accepted: 18-01-2016 \\ Corresponding Author: \\ Sharifah Norkhadijah Syed \\ Ismail, \\ Department of Environmental \\ and Occupational Health, \\ Faculty of Medicine and Health \\ Sciences, Universiti Putra \\ Malaysia (UPM), 43400 \\ Serdang, Selangor, Malaysia \\ Email: norkhadijah@upm.edu.my
}

\section{Introduction}

Nitrate contamination is one of the most widespread groundwater problems worldwide (Almasri, 2007; Gupta et al., 2008). Nitrate contamination in groundwater arise from point sources such as livestock facilities, sewage disposal systems, including septic tanks and non-point sources such as fertilized cropland, or naturally occurring sources of nitrogen (Manassaram et al., 2006; Yang et al., 2007;

\begin{abstract}
High concentrations of nitrate through drinking water have been associated with health problems. This cross sectional study sought to determine the level of nitrate concentrations in private well water and the association to the disease caused by nitrate among population of Bachok, Kelantan. The concentrations of nitrate in 256 wells were sampled from September to October 2015. About 126 respondents from the agricultural area and 130 respondents from the non-agricultural area were participated in the study. The human health risk associated with ingesting nitrate were assessed by Hazard Quotient (HQ) and Odd Ratio (OR). The physicochemical characteristics of well water in both areas (i.e., pH, ammonia, Dissolved Oxygen (DO), conductivity, turbidity, Total Dissolved Solid (TDS) and salinity) were within the acceptable limits of Malaysian Drinking Water Quality Standard. The mean \pm SD levels of nitrate in the agricultural area was $13.04 \pm 14.39 \mathrm{mg} \mathrm{L}^{-1} \mathrm{NO}_{3}-\mathrm{N}$, exceeding the maximum acceptable limits of Malaysia NDWQS $\left(10 \mathrm{mg} \mathrm{L}^{-1} \mathrm{NO}_{3}-\mathrm{N}\right)$ and were two fold higher than the non-agriculture area $\left(6.31 \pm 5.22 \mathrm{mg} \mathrm{L}^{-1}\right.$ $\left.\mathrm{NO}_{3}-\mathrm{N}\right) .52$ wells $(41.27 \%)$ in the agricultural area and 35 wells $(26.9 \%)$ in the non-agricultural area had nitrate level above the maximum acceptable nitrate $\left(10 \mathrm{mg} \mathrm{L}^{-1} \mathrm{NO}_{3}-\mathrm{N}\right)$. The $\mathrm{HQ}$ associated with the potential non-carcinogenic risk of drinking nitrate contaminated groundwater ranged from 0.007 to $1.143 \times 10^{-6}$ in the agricultural area, slightly higher than in the non-agricultural area $\left(0.002\right.$ to $\left.0.468 \times 10^{-6}\right)$. The OR for disease such as diabetes, goitre and gastric were not significant with high levels of nitrate in the well water. The results of the present study showed that there was no statistically significant association between nitrate in well water and the risk of related health disease such as diabetes, goitre and gastric in this study.
\end{abstract}

Keywords: Nitrate, Groundwater, Agricultural Area, Health Risk, Drinking Water 
Many factors influence the occurrence and concentration of nitrate in groundwater. Water from shallow wells (less than 100 feet below land surface) in areas with well-drained soils and high nitrogen inputs (e.g., proximity to agricultural areas) possibly have nitrate-rich groundwater (Manassaram et al., 2006). Private wells are usually shallower and are closer to sources of nitrate contamination, whereas public supply wells are usually in deeper groundwater aquifers where contamination is less likely (Manassaram et al., 2006). High nitrate concentration in drinking water causes health problems such as methemoglobinemia (blue baby syndrome) in infants, thyroid disorders, spontaneous abortions and birth defects and cancer in adults (Almasri, 2007; Gupta et al., 2008; Chang et al., 2010). As such, the U.S. Environmental Protection Agency (EPA) has established Maximum Contaminant Level (MCL) for nitrate in drinking water of $10 \mathrm{mg} \mathrm{L}^{-1}$ nitrate-nitrogen $\left(\mathrm{NO}_{3}-\mathrm{N}\right)$ and the World Health Organization (WHO) guideline of $11 \mathrm{mg} \mathrm{L}^{-1}$ as $\mathrm{NO}_{3}-\mathrm{N}$ were promulgated to protect against methemoglobinemia (Ward et al., 2005). However, this standard applies only to public water supplies, not to private wells and it was not based on the estimates of cancer risk (Ward et al., 2003). The effectiveness of this regulatory limit for preventing other health risks such as cancer has not been adequately studies (Yang et al., 2007).

In Malaysia, the demand for water has increased tremendously and groundwater has been identified as one of the alternatives to new sources. In Kelantan, almost $70 \%$ of people consumes groundwater in their daily lives (Zawawi et al., 2010). However, due to uncontrolled development and human activities, groundwater is subjected to pollution. The shallow aquifer system in the Kelantan river delta constitutes an important source of water not only for public water supply, but also for domestic and agricultural purposes. Being shallow and relatively unprotected, the aquifer is generally exposed to higher risk of nitrate contamination due to anthropogenic activities at the surface. In Kelantan, the climate changes are obvious and produce significant impacts on groundwater levels which contribute towards the nitrate contamination of groundwater in the shallow aquifers.

The objectives of this study were to determine the level of nitrate in the well water and the association to the disease caused by nitrate among population of Bachok, Kelantan. This study provides baseline data on the level of nitrate in the groundwater and the evaluation of health hazard risk by hazard quotient method and the possible association with the health symptoms among the population. The results of this study may be beneficial in establishing a groundwater protection plan to support the sustainable utilization of groundwater resources in Kelantan.

\section{Materials and Methods}

\section{Study Area}

A cross-sectional study was performed in Bachok, Kelantan $\left(6^{\circ} 4^{\prime} 0\right.$ " North and $102^{\circ} 24^{\prime} 0$ " East), a northeastern state in Peninsular Malaysia (Fig. 1). The study was conducted from September to October 2014. Paddy cultivation is the main activity of Bachok population. Almost $70 \%$ of community in Kelantan used groundwater for drinking (Zawawi et al., 2010). Problems such as dirty and smelly water supply, low coverage performance and frequent water disruption had caused the population to use groundwater as their alternative water sources (Kamaludin et al., 2013). However, groundwater is subjected to pollution due to uncontrolled development and human activities such as agriculture. Two areas were selected for this study, agricultural area (focus on paddy field) and nonagricultural area for comparison.

\section{Data Collection}

This study utilised questionnaire as a tool. A set of structured questionnaires were used in this study which comprised of three sections. The first section contained questions regarding respondent's background information such as the age, gender, education, monthly income and duration of residence. The second section contained questions regarding water consumption and physical characteristics of the respondent's well while in the third section contained the questions about the health status of respondents. Consent forms were obtained from each respondent before interview prior to the interview. The respondents were informed that the questionnaires could be answered voluntarily, anonymously and the information would be treated confidentially. The interviews took approximately $10 \mathrm{~min}$.

Well water was sampled from 256 private wells (126 wells in the agriculture site and 130 wells in the nonagriculture site) during wet season of 2014 (September to October). The well water was collected using the High-Density of Polyethylene (HDPE) bottles.

The bottles were cleaned by soaking them in diluted $\mathrm{HNO}_{3}$ for $24 \mathrm{~h}$ and they were washed thoroughly with deionised water and dried before water sampling. Chemical properties of well water such as $\mathrm{pH}$, temperature, dissolve oxygen, conductivity, turbidity, TDS and salinity were measured using YSI Professional Plus handled multiparameter meter. The samples were stored in an ice-box and transported to the lab immediately. The analysis of nitrate was carried out using a Cadmium Reduction Method (Method 8171) with a HACH brand of DR/2500 spectrophotometer. 

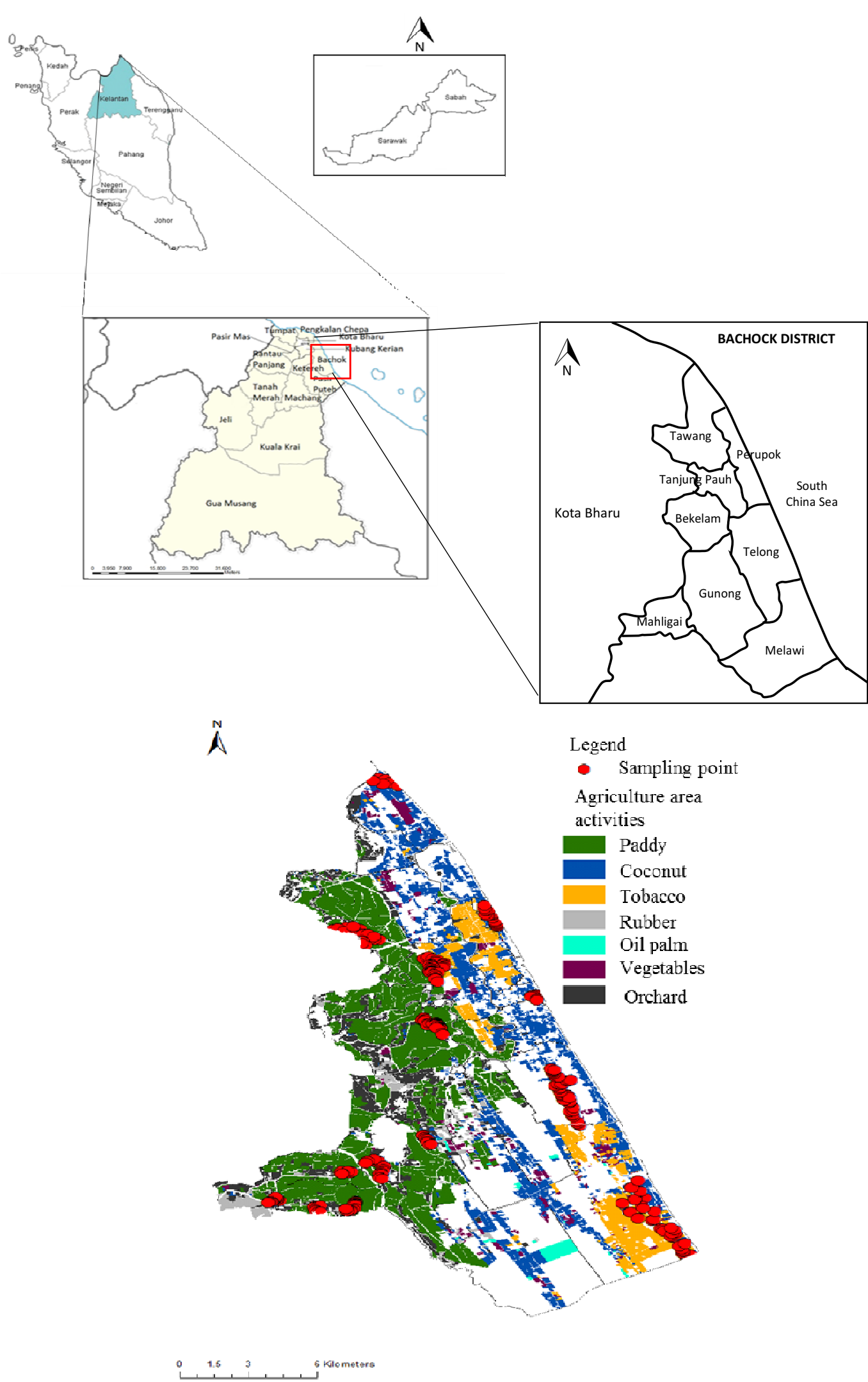

Fig. 1. Study area and distribution of agricultural area in Bachok 


\section{Human Health Risk Assessment}

The non-cancer health risk associated with drinking nitrate contaminated water was assessed herein. A method for estimating the Target Hazard Quotient (THQ) by the US EPA Regional Risk-Based Concentration Table was used (Liu et al., 2011). The risk associated with the non-cancer effects of nitrate through drinking water is expressed as follows:

$$
T H Q=\frac{C \times E F \times E D \times I R}{(R f D \times B W \times A T)}
$$

Where:

$C=$ The nitrate concentrations $(\mathrm{mg} / \mathrm{L})$

$E F=$ The exposure frequency (350 days/year)

$E D=$ The duration of exposure ( 30 years)

$I R=$ The amount of water ingested by an adult, $(2 \mathrm{~L} /$ day $)$

$R f D=$ The oral reference dose $\left(1.6 \mathrm{mg} / \mathrm{L} /\right.$ day of $\left.\mathrm{NO}_{3}-\mathrm{N}\right)$

$B W=$ The body weight of an adult $(60 \mathrm{~kg})$

$A T=$ The averaging time for non-carcinogens $(30$ years $\times 365$ days $/$ year $=10,950$ days )

An acceptable standard human health risk by drinking water is a $T H Q$ value of under unity (Liu et al., 2011).

\section{Statistical Analysis}

Data from questionnaire, nitrate and in-situ parameters concentrations in the well water of both areas were analysed using IBM Statistical Package for Social Sciences (SPSS) version 21.0. KolmogorovSmirnov, Shapiro Wilk and Skewness tests were used to check the normality of distribution of the interval/ratio scale variables. Data in this study were non-normally distributed $(\mathrm{p}<0.05)$, thus nonparametric statistics were used. Chi-square, Mann-Whitney and Kruskal-Wallis Test were used to test for differences between the variables. The Spearman correlation analysis was used to determine whether definable statistical relationships exist between the observed nitrate concentration and several variables. The Spearman correlation coefficient $r_{s}$ shows the strength of the relationship and whether the relationship is positive or negative; the $\mathrm{p}$ value shows the significant level of test. Odd Ratios (ORs) and their 95\% confidence interval $(95 \% \mathrm{CI})$ were calculated using the respondents in the non-agricultural area as the reference group. Values of $p<0.05$ were considered statistically significant.

\section{Results}

\section{Respondent's Background}

A total of 126 respondents from the agricultural area and 130 respondents from the non-agricultural area were participated in the study (Fig. 1). Majority of the respondents are female where $67(53.6 \%)$ of them in agricultural area and $71(54.6 \%)$ in the nonagricultural area (Table 1). Most of respondents in both areas are married $(\mathrm{N}=109$ in the agricultural area; $\mathrm{N}=114$ in the non-agricultural area). The respondents aged ranged from 18-91 years old. All of the respondents are Malays. Majority of respondents in these areas had the highest qualification from secondary school $(\mathrm{N}=53$ in the agricultural area, $\mathrm{N}=$ 50 in non-agricultural area). Most of them are selfemployed (61 (48\%) in the agricultural area and 56 $(43.1 \%)$ in the non-agricultural area). About $37.0 \%$ respondents in the agricultural area and $40.0 \%$ respondents in non-agricultural area do not have permanent income. The average income for the population is less than RM 500 per month $(25.2 \%$ in the agricultural area and $25.4 \%$ in the non-agricultural area) and between Malaysia Ringgit (RM) 500 to RM $1500(22 \%$ in the agricultural area and $20.8 \%$ in the non-agricultural area). Majority of respondents had lived in the study area for more than 30 years $(59.5 \%$ in the agricultural area and $58.55 \%$ in the nonagricultural area). The chi square test indicates no significant difference in socio-demographic background of respondents in this study (Table 1).

\section{Physicochemical Characteristics of Well Water}

Table 2 shows the physicochemical characteristics of well water in this study. The mean $\pm \mathrm{SD}$ of $\mathrm{pH}$ values of well water in the agricultural area was significantly lower $(5.64 \pm 0.32)$ compared to the nonagricultural area $(6.32 \pm 0.76)(Z=-8.30 ; p<0.001)$. The mean $\mathrm{pH}$ of well water in both areas do not fall within the Malaysia National Drinking Water Quality Standard (NDWQS) (6.5 to 9.00). The well water in the agricultural area were slightly acidic compared to the non-agricultural area.

The mean \pm SD of ammonia in the agricultural area was significantly higher $\left(0.84 \pm 1.32 \mathrm{mg} \mathrm{L}^{-1}\right)$ compared to the non-agricultural area $\left(0.24 \pm 0.41 \mathrm{mg} \mathrm{L}^{-1}\right)(\mathrm{Z}=-7.82$; $\mathrm{p}<0.001)$. The ammonia level in the well water for both areas was within the maximum level of NDWQS $\left(1.5 \mathrm{mg} \mathrm{L}^{-1}\right)$.

The Mean \pm SD of conductivity in the well water in agriculture area was significantly lower $\left(94.67 \pm 60.80 \mu \mathrm{S} \mathrm{cm}^{-1}\right)$ than the non-agricultural area $\left(205.14 \pm 209.11 \mu \mathrm{S} \mathrm{cm}{ }^{-1}\right)(Z=-4.81, \mathrm{p}<0.001)$. The NDWQS has no guideline value for conductivity however, WHO has set a limit to $500 \mu \mathrm{S} \mathrm{cm}^{-1}$. The mean of conductivity values in both areas in this study were below than the WHO acceptable limit.

The well water in the agriculture area has significantly higher turbidity compared to the non-agriculture area with the Mean \pm SD of $5.06 \pm 9.65$ NTU and $2.94 \pm 3.78$ NTU respectively $(Z=-3.96, p<0.001)$ (Table 2$)$. 
Table 1. The socio-demographic background of respondents in the agricultural and non-agricultural areas $(\mathrm{n}=256)$

\begin{tabular}{lll}
\hline Variables & Agricultural area & Non-agricultural area \\
\hline & $(\mathrm{N}=126)$ & $(\mathrm{N}=130)$ \\
Gender & $\mathrm{n}(\%)$ & $\mathrm{n}(\%)$ \\
Male & $58(46.4)$ & $59(45.4)$ \\
Female & $67(53.6)$ & $71(54.6)$ \\
Marital status & & \\
Single & $16(12.6)$ & $16(12.3)$ \\
Married & $109(85.8)$ & $114(87.7)$ \\
Education & $17(13.4)$ & $17(13.1)$ \\
None & $39(30.7)$ & $44(33.8)$ \\
Primary school & $53(41.7)$ & $50(38.5)$ \\
Secondary school & $3(2.4)$ & $3(2.3)$ \\
Certificate & $8(6.3)$ & $8(6.2)$ \\
Diploma & $5(3.9)$ & $8(6.2)$ \\
Bachelor's degree & & \\
Employment & $9(7.1)$ & $9(6.9)$ \\
Government sector & $9(7.1)$ & $14(10.8)$ \\
Private sector & $61(48.0)$ & $56(43.1)$ \\
Self-employed & $43(33.9)$ & $47(36.2)$ \\
Unemployed & $3(2.4)$ & $4(3.1)$ \\
Student & $32(25.2)$ & $33(25.4)$ \\
Income (RM) & $28(22.0)$ & $27(20.8)$ \\
<500 & $17(13.4)$ & $14(10.8)$ \\
$500-1500$ & $1(0.8)$ & $4(3.1)$ \\
$1501-3500$ & $47(37.0)$ & $52(40.0)$ \\
$>3500$ & $12(9.5)$ & $22(16.9)$ \\
Do not have permanent income & $38(30.2)$ & $32(24.6)$ \\
Period of residency (year) & $75(59.5)$ & $76(58.5)$ \\
$\geq 10-20$ & &
\end{tabular}

Chi Square Test, * Significant at level $\mathrm{p}<0.05$

Table 2. The physicochemical characteristics of well water in the agriculture and non-agriculture area $(\mathrm{n}=256)$

\begin{tabular}{|c|c|c|c|}
\hline Parameters & Agricultural area $(\mathrm{N}=126)$ & Non-agricultural area $(\mathrm{N}=130)$ & $\mathrm{Z}$ value \\
\hline \multicolumn{4}{|l|}{ pH } \\
\hline Mean \pm SD & $5.64 \pm 0.32$ & $6.32 \pm 0.76$ & \multirow[t]{3}{*}{$-8.30^{* *}$} \\
\hline Median & 5.68 & 6.48 & \\
\hline \multirow{2}{*}{\multicolumn{4}{|c|}{ Ammonia (mg/L) }} \\
\hline & & & \\
\hline Mean \pm SD & $0.84 \pm 1.32$ & $0.24 \pm 0.4$ & \multirow{3}{*}{$-7.82^{* *}$} \\
\hline Median & 0.28 & 0.12 & \\
\hline Range & $0.05-6.81$ & $0.02-2.42$ & \\
\hline \multicolumn{4}{|c|}{ Dissolved Oxygen (mg/L) } \\
\hline Mean \pm SD & $6.37 \pm 1.07$ & $9.63 \pm 1.71$ & \multirow[t]{3}{*}{$-12.75^{* *}$} \\
\hline Median & 6.21 & 9.22 & \\
\hline Rang & $3.75-9.96$ & $6.13-13.67$ & \\
\hline \multicolumn{4}{|c|}{ Conductivity (uS/cm) } \\
\hline Mean \pm SD & $94.67 \pm 60.80$ & $205.14 \pm 209.11$ & \multirow[t]{3}{*}{$-4.81^{* *}$} \\
\hline Median & 73.47 & 147.84 & \\
\hline Rang & $25.40-287.50$ & $16.20-1251.67$ & \\
\hline \multicolumn{4}{|c|}{ Turbidity (NTU) } \\
\hline Mean \pm SD & $5.10 \pm 9.65$ & $2.94 \pm 3.78$ & \multirow[t]{3}{*}{$-3.96^{* *}$} \\
\hline Median & 2.63 & 1.33 & \\
\hline Rang & $0.28-69.80$ & $0.15-16.60$ & \\
\hline \multicolumn{4}{|c|}{ Total Dissolved Solids (TDS) (mg/L) } \\
\hline Mean \pm SD & $69.34 \pm 46.09$ & $165.08 \pm 173.65$ & \multirow[t]{3}{*}{$-5.16^{* *}$} \\
\hline Median & 56.55 & 126.43 & \\
\hline Range & $15.60-214.5$ & $12.35 \pm 1007.50$ & \\
\hline \multicolumn{4}{|c|}{ Salinity (ppt) } \\
\hline Mean \pm SD & $0.05 \pm 0.04$ & $0.13 \pm 0.17$ & \multirow[t]{3}{*}{$-5.28^{* *}$} \\
\hline Median & 0.04 & 0.09 & \\
\hline Range & $0.01-0.16$ & $0.01-1.25$ & \\
\hline
\end{tabular}

Mann-Whitney U Test, ${ }^{* *}$ Significant at $\mathrm{p}<0.001$ 
The mean turbidity value in agricultural area was fairly above the WHO acceptable limit of 5.00 NTU. The Mean \pm SD of Total Dissolved Solid (TDS) in the nonagricultural area was significantly higher $\left(165.08 \pm 173.65 \mathrm{mg} \mathrm{L}^{-1}\right)$ compared to the agricultural area $\left(69.34 \pm 46.09 \mathrm{mg} \mathrm{L}^{-1}\right)(Z=5.16, \mathrm{p}<0.001)$. The TDS for both areas do not exceed the Malaysia NDWQS (1000 $\left.\mathrm{mg} \mathrm{L}^{-1}\right)$. The salinity of well water in nonagriculture area was significantly higher than the agriculture area with the mean $\pm \mathrm{SD}$ of $0.05 \pm 0.04 \mathrm{ppt}$ and $0.13 \pm 0.17$ ppt respectively $(Z=-5.28 ; \mathrm{p}<0.001)$.

\section{Nitrate Concentration in Well Water}

Table 3 shows the concentration of nitrate in the well water. The Mean \pm SD of nitrate in agriculture area was significantly higher $\left(13.04 \pm 14.39 \mathrm{mg} \mathrm{L}^{-1} \mathrm{NO}_{3}-\mathrm{N}\right)$ than the non-agriculture area $\left(6.31 \pm 5.22 \mathrm{mg} \mathrm{L}^{-1} \mathrm{NO}_{3}-\mathrm{N}\right)(\mathrm{Z}=$ $3.554, \mathrm{p}<0.001)$. The nitrate level in the agricultural area has exceeded the Malaysia NDWQS (10 mg L $\left.\mathrm{m}^{-1} \mathrm{NO}_{3}-\mathrm{N}\right)$. The natural levels of nitrate in groundwater are usually less than $3 \mathrm{mg} \mathrm{L}^{-1} \mathrm{NO}_{3}-\mathrm{N}$ and nitrate concentration exceeding the threshold of $3 \mathrm{mg} \mathrm{L}^{-1} \quad \mathrm{NO}_{3}-\mathrm{N}$ is considered as contaminated due to human activities (the so-called human affected value) (Babiker et al., 2004; Pastén-Zapata et al., 2014). The maximum acceptable levels of nitrate in drinking water is set at value $10 \mathrm{mg} \mathrm{L}^{-1} \mathrm{NO}_{3}-\mathrm{N}$ according to Malaysia NDWQS. This value is the limit to protect against methemoglobinemia in infants (Ward et al., 2005). Therefore, the concentration of nitrate in well waters in this study were categorised into three categories which is $<3 \mathrm{mg} \mathrm{L}^{-1} \mathrm{NO}_{3}-\mathrm{N}$, between 3 to $10 \mathrm{mg} \mathrm{L}^{-1} \mathrm{NO}_{3}-\mathrm{N}$ and $>10 \mathrm{mg} \mathrm{L}^{-1} \mathrm{NO}_{3}-\mathrm{N}$.

There were 49 wells (38.89\%) in agricultural area and 44 wells in non-agricultural area had nitrate levels exceeding $3 \mathrm{mg} \mathrm{L} \mathrm{L}^{-1} \mathrm{NO}_{3}-\mathrm{N}$ indicating a contamination due to human activities. About 52 wells (41.27\%) in the agricultural area and 35 wells (26.9\%) in the nonagricultural area had nitrate levels above $10 \mathrm{mg} \mathrm{L}^{-1} \mathrm{NO}_{3}{ }^{-}$ $\mathrm{N}$ which is not suitable for being drinking water. 25 wells $(19.84 \%)$ in the agricultural area and 44 wells $(39.23 \%)$ in the non-agriculture had nitrate value less than $3 \mathrm{mg} \mathrm{L}^{-1}$, indicating a natural levels of nitrate in groundwater.

\section{The Relationship between Physical Characteristics of Well and Nitrate Concentration}

Table 4 shows the well characteristic in this study. Majority of the wells are 20 years of age with a depth 1 to $5 \mathrm{~m}$. Majority of the wells are located between 5 to 10 $\mathrm{m}$ from the septic tank $(\mathrm{N}=123$ in agriculture area and 90 in non-agriculture area) and 20 to $30 \mathrm{~m}$ from their neighbours septic tank. Most of the well is located within the range of 50 to $200 \mathrm{~m}$ from the agriculture area and less than $50 \mathrm{~m}$ from the livestock farm.

There was no significant relationship between nitrate level and well characteristics. In general, the Mean \pm SD of nitrate in the well of less than 20 years was higher $\left(18.79 \pm 19.77 \mathrm{mg} \mathrm{L}^{-1} \mathrm{NO}_{3}-\mathrm{N}\right)$ than well aged $>20$ years $\left(12.41 \pm 13.32 \mathrm{mg} \mathrm{L}^{-1} \mathrm{NO}_{3}-\mathrm{N}\right)$. High nitrate was detected in shallow well (depth $<1-5 \mathrm{~m}$ ) in the agricultural area with the Mean $\pm \mathrm{SD}$ of $13.41 \pm 13.84 \mathrm{mg} \mathrm{L}^{-1} \mathrm{NO}_{3}-\mathrm{N}$. Nitrate was also high in the well with high turbidity during rainy day especially in the agricultural area $\left(13.61 \pm 14.02 \mathrm{mg} \mathrm{L}^{-1} \mathrm{NO}_{3}-\mathrm{N}\right)$.

Elevated nitrate concentrations also were detected in the well located $200 \mathrm{~m}$ from the paddy field. The Mean \pm $\mathrm{SD}$ of nitrate was $13.15 \pm 13.11 \mathrm{mg} \mathrm{L}^{-1} \mathrm{NO}_{3}-\mathrm{N}$ for $0-50 \mathrm{~m}$ distance, $10.46 \pm 10.62 \mathrm{mg} \mathrm{L}^{-1} \mathrm{NO}_{3}-\mathrm{N}$ for $50-100 \mathrm{~m}$ and $15.15 \pm 17.09 \mathrm{mg} \mathrm{L}^{-1} \mathrm{NO}_{3}-\mathrm{N}$ for $100-200 \mathrm{~m}$. High nitrate also was determined in the well $<50 \mathrm{~m}$ to the livestock area with the Mean $\pm \mathrm{SD}$ of $15.92 \pm 11.42 \mathrm{mg} \mathrm{L}^{-1} \mathrm{NO}_{3}-\mathrm{N}$ in the agricultural area.

Nitrate was high in a well located near to septic tank. For example, the Mean \pm SD of nitrate in the well with distance of 5 to $10 \mathrm{~m}$ to septic tank was $13.31 \pm 14.45$ $\mathrm{mg} \mathrm{L}^{-1} \mathrm{NO}_{3}-\mathrm{N}, 14.54 \pm 14.54 \mathrm{mg} \mathrm{L}^{-1}$ for 20 to $30 \mathrm{~m}$ from septic tank and $17.40 \pm 19.36 \mathrm{mg} \mathrm{L}^{-1} \mathrm{NO}_{3}-\mathrm{N}$ for 30 to 40 $\mathrm{m}$ from a septic tank in the agriculture sites. High nitrate also was detected in the well located $15-20 \mathrm{~m}$ to the septic tank (10.56 mg L $\left.{ }^{-1} \mathrm{NO}_{3}-\mathrm{N}\right)$ in the non-agriculture sites. The highest nitrate also was detected in the well located 30 to $40 \mathrm{~m}\left(17.40 \pm 19.36 \mathrm{mg} \mathrm{L}{ }^{-1} \mathrm{NO}_{3}-\mathrm{N}\right)$ from neighbour's septic tank in the agricultural area.

\section{Correlation between Chemical Parameters}

High positive correlation was found between conductivity with TDS and salinity with the $\mathrm{r}$ value $=$ $0.980 \quad(\mathrm{p}<0.001) \quad($ Table 5). Nitrate also showed significant positive relationship with ammonia ( $\mathrm{r}=$ $0.411, \mathrm{p}<0.001)$, conductivity $(\mathrm{r}=0.502, \mathrm{p}<0.001)$, TDS $(\mathrm{r}=0.480, \mathrm{p}<0.001)$ and salinity $(\mathrm{r}=0.485, \mathrm{p}<0.001)$.

\section{Human Health Risk Assessment and Health Status of Respondents}

The level of nitrate ingestion from drinking water was ranged from 0.007 to $1.143 \times 10^{-6}$ in the agricultural area and 0.002 to $0.468 \times 10^{-6}$ in the non-agricultural area. The highest nitrate concentration $\left(57.23 \mathrm{mg} \mathrm{L}^{-1} \mathrm{NO}_{3}-\mathrm{N}\right)$ in the well water has THQ value of 1.143 which exceeds the acceptable standard, indicating a potential non-cancer risk for Bachok residents.

Table 6 shows the odd ratio of diseases caused by nitrate in the agricultural and non-agricultural area in this study. There was no significant association between nitrate exposure and health. Out of 256 respondents in this study, only $1(0.8 \%)$ of them has diabetes type I and $8(6.3 \%)$ have diabetes type II in the agricultural area. While in the non-agricultural area, only 2 of the respondents (1.5\%) have diabetes type I and 7 (5.4\%) have diabetes type II. Only one respondent $(0.8 \%)$ from each group has goitre 
disease. In addition, $50 \%(\mathrm{n}=63)$ of respondents in the agricultural area and $43.8 \%(n=57)$ of respondents in the non-agricultural area have gastric. The ORs for diseases such as diabetes, goitre and gastric were not significant related to nitrate. The ORs for the studied areas were 0.512 $(\mathrm{CI}=0.04-5.72)$ for diabetes type $\mathrm{I}, \mathrm{OR}=1.191(\mathrm{CI}=0.42$ $3.39)$ for diabetes type II, OR $=1.03(\mathrm{CI}=0.06-16.68)$ for goitre and $\mathrm{OR}=1.28(\mathrm{CI}=0.78-2.09)$ for gastric.

Table 3. Comparison of nitrate concentration in the agricultural and non-agricultural area $\left(\mathrm{mg} / \mathrm{L} \mathrm{NO}_{3}-\mathrm{N}\right)(\mathrm{n}=256)$

\begin{tabular}{llll}
\hline Descriptive statistics & Agricultural area & ${ }^{(\mathrm{N}=126)}$ & Non-agricultural area \\
\hline Mean $\pm \mathrm{SD}$ & $13.04 \pm 14.39$ & $6.31 \pm 5.22$ & $\mathrm{Z}$ value \\
Median & 6.695 & 4.907 & $0.11-23.45$ \\
Range & $0.36-57.23$ & $39.23 \%(51)$ & $-3.554^{* *}$ \\
$<3 \mathrm{mg} \mathrm{L}^{-1} \mathrm{NO}_{3}-\mathrm{N}(\mathrm{N})$ & $19.84 \%(25)$ & $33.85 \%(44)$ & $26.92 \%(35)$ \\
$\geq 3-10 \mathrm{mg} \mathrm{L}^{-1} \mathrm{NO}_{3}-\mathrm{N}(\mathrm{N})$ & $38.89 \%(49)$ & $41.27 \%(52)$ & \\
$>10 \mathrm{~m} \mathrm{~L}^{-1} \mathrm{NO}_{3}-\mathrm{N}(\mathrm{N})$ & &
\end{tabular}

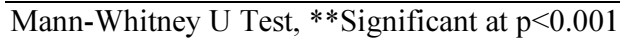

Table 4. Physical properties of well and nitrate concentration $(n=256)$

\begin{tabular}{|c|c|c|c|c|c|c|c|c|}
\hline \multirow[b]{2}{*}{ Well information } & & \multicolumn{3}{|c|}{ Agricultural area $(\mathrm{N}=126)$} & \multicolumn{3}{|c|}{ Non-agricultural area $(\mathrm{N}=130)$} & \multirow{2}{*}{$\begin{array}{l}\text { Sig. } \\
\text { level of } \\
\text { test }(p)\end{array}$} \\
\hline & & No. of well & $\begin{array}{l}\text { Mean } \pm \mathrm{SD} \\
(\mathrm{mg} / \mathrm{L})\end{array}$ & $\begin{array}{l}\text { Range } \\
(\mathrm{mg} / \mathrm{L})\end{array}$ & No. of well & $\begin{array}{l}\text { Mean } \pm \mathrm{SD} \\
(\mathrm{mg} / \mathrm{L})\end{array}$ & $\begin{array}{l}\text { Range } \\
(\mathrm{mg} / \mathrm{L})\end{array}$ & \\
\hline \multirow[t]{3}{*}{ Age of well (year) } & $>10-15$ & 6 & $5.39 \pm 3.59$ & $2.31-10.37$ & 5 & $3.00 \pm 3.30$ & $0.89-8.85$ & 0.391 \\
\hline & $>15-20$ & 19 & $18.79 \pm 19.77$ & $2.84-56.78$ & 15 & $6.98 \pm 4.88$ & $0.22-15.55$ & \\
\hline & $>20$ & 101 & $12.41 \pm 13.32$ & $0.36-57.23$ & 110 & $6.37 \pm 5.31$ & $0.11-23.45$ & \\
\hline \multirow[t]{3}{*}{ Depth of well (m) } & $<1-5$ & 88 & $13.41 \pm 13.84$ & $1.16-49.38$ & 112 & $6.56 \pm 5.35$ & $0.22-23 . .45$ & 0.355 \\
\hline & $>5-10$ & 33 & $12.44 \pm 16.29$ & $0.36-57.23$ & 12 & $4.37 \pm 3.29$ & $0.88-9.33$ & \\
\hline & $>10-30$ & 5 & $10.33 \pm 12.91$ & $3.76-33.35$ & 6 & $5.43 \pm 5.55$ & $0.11-10.58$ & \\
\hline \multirow[t]{2}{*}{ Turbid during rainy day } & Yes & 53 & $13.61 \pm 14.02$ & $0.36-45.18$ & 59 & $5.48 \pm 4.86$ & $0.11-22.26$ & 0.313 \\
\hline & No & 73 & $12.62 \pm 14.73$ & $1.28-57.23$ & 71 & $6.99 \pm 5.43$ & $0.22-23.45$ & \\
\hline \multirow{5}{*}{$\begin{array}{l}\text { Distance of septic } \\
\text { tank to well (m) }\end{array}$} & $0-5$ & 1 & 3.09 & 3.09 & 21 & $6.79 \pm 4.37$ & $0.88-13$ & 0.794 \\
\hline & $>5-10$ & 123 & $13.31 \pm 14.45$ & $0.51-57.23$ & 90 & $6.37 \pm 5.75$ & $0.11-23.45$ & \\
\hline & $>10-15$ & 0 & - & - & 0 & - & - & \\
\hline & $>15-20$ & 1 & 1.62 & 1.62 & 1 & 10.56 & 10.56 & \\
\hline & Not sure & 1 & 0.36 & 0.36 & 18 & $5.01 \pm 3.03$ & $1.09-10.58$ & \\
\hline \multirow{5}{*}{$\begin{array}{l}\text { Distance of neighbour's } \\
\text { septic tank to well (m) }\end{array}$} & $>10-20$ & 11 & $10.96 \pm 12.10$ & $2.13-44.02$ & 38 & $5.94 \pm 4.47$ & $0.88-13.34$ & 0.53 \\
\hline & $>20-30$ & 57 & $14.54 \pm 14.54$ & $0.51-56.78$ & 42 & $6.28 \pm 6.11$ & $0.11-22.77$ & \\
\hline & $>30-40$ & 12 & $17.41 \pm 19.36$ & $2.22-54.88$ & 4 & $6.74 \pm 6.72$ & $0.44-12.88$ & \\
\hline & $>40$ & 2 & $2.69 \pm 1.51$ & $1.62-3.76$ & 2 & $10.34 \pm 0.32$ & $10.11-10.56$ & \\
\hline & Not sure & 44 & $10.88 \pm 13.31$ & $0.36-57.23$ & 44 & $6.42 \pm 4.99$ & $0.22-23.45$ & \\
\hline \multirow{5}{*}{$\begin{array}{l}\text { Distance of agricultural } \\
\text { area to well }(\mathrm{m})\end{array}$} & $0-50$ & 23 & $13.15 \pm 13.11$ & $0.51-44.02$ & - & - & - & 0.371 \\
\hline & $>50-100$ & 35 & $10.46 \pm 10.62$ & $0.36-40.12$ & - & - & - & \\
\hline & $>100-200$ & 46 & $15.15 \pm 17.09$ & $1.51-57.23$ & - & - & - & \\
\hline & $>200-500$ & 10 & $4.41 \pm 2.11$ & $1.28-7.66$ & - & - & - & \\
\hline & Not sure & 12 & $19.41 \pm 17.60$ & $1.16-49.12$ & - & - & - & \\
\hline \multirow{3}{*}{$\begin{array}{l}\text { Distance of livestock } \\
\text { area to well }(\mathrm{m})\end{array}$} & $0-50$ & 15 & $15.92 \pm 11.42$ & $2.22-33.35$ & 18 & $5.75 \pm 4.20$ & $1.44-15.58$ & 0.4 \\
\hline & $>50-100$ & 6 & $12.37 \pm 10.43$ & $6.65-10.37$ & 7 & $3.91 \pm 3.55$ & $1.10-11.03$ & \\
\hline & Not sure & 4 & $8.94 \pm 6.88$ & $3.00-17.14$ & 3 & $5.18 \pm 6.20$ & $1.11-12.32$ & \\
\hline
\end{tabular}

Table 5. The Spearman correlation coefficients of the different groundwater parameters $(n=256)$

\begin{tabular}{|c|c|c|c|c|c|c|c|c|}
\hline & $\mathrm{pH}$ & Nitrate & Ammonia & DO & $\mathrm{EC}$ & Turbidity & TDS & Salinity \\
\hline$\overline{\mathrm{pH}}$ & 1.000 & & & & & & & \\
\hline Nitrate & 0.007 & 1.000 & & & & & & \\
\hline Ammonia & 0.010 & $0.411^{* *}$ & 1.000 & & & & & \\
\hline DO & $0.451^{* *}$ & $-0.211^{* *}$ & $-0.290^{* *}$ & 1.000 & & & & \\
\hline $\mathrm{EC}$ & $0.646^{* *}$ & $0.502^{* *}$ & $0.419^{* *}$ & $0.226^{* *}$ & 1.000 & & & \\
\hline Turbidity & 0.057 & $-0.181^{* *}$ & 0.108 & $-0.151^{*}$ & -0.100 & 1.000 & & \\
\hline TDS & $0.658^{* *}$ & $0.480^{* *}$ & $0.435^{* *}$ & $0.291^{* *}$ & $0.990^{* *}$ & -0.096 & 1.000 & \\
\hline Salinity & $0.660^{* *}$ & $0.485^{* *}$ & $0.421^{* *}$ & $0.303^{* *}$ & $0.980^{* *}$ & -0.112 & $0.980^{* *}$ & 1.000 \\
\hline
\end{tabular}

Correlations are significant at $\mathrm{p}<0.05,{ }^{* *}$ Correlations are significant at $\mathrm{p}<0.001$ 
Table 6. Diseases caused by nitrate in the agricultural and non-agricultural area $(n=256)$

\begin{tabular}{llll}
\hline Disease & Agricultural area & Non-agricultural area & Odd ratio (95\% CI) \\
\hline Diabetes type I & $1(0.8 \%)$ & $2(1.5 \%)$ & $0.51(0.05-5.72)$ \\
Diabetes type II & $8(6.3 \%)$ & $7(5.4 \%)$ & $1.19(0.42-3.39)$ \\
Goitre & $1(0.8 \%)$ & $1(0.8 \%)$ & $1.03(0.06-16.68)$ \\
Gastric & $63(50.0 \%)$ & $57(43.8 \%)$ & $1.28(0.78-2.09)$ \\
\hline
\end{tabular}

\section{Discussion}

The well water in the agricultural area were slightly acidic compared to the non-agricultural area. This possibly due to the present of dissolved carbon dioxides $\left(\mathrm{CO}_{2}\right)$ and biocarbonates in the aquiferous rocks (Igboekwe et al., 2011). Under natural condition, $\mathrm{H}^{+}$in the groundwater may be derived from dissociation of $\mathrm{H}_{2} \mathrm{CO}_{3}$ as well as from the acidity of rainwater. The $\mathrm{H}_{2} \mathrm{CO}_{3}$ in the groundwater is formed by dissolution of $\mathrm{CO}_{2}$, which comes mainly from the biological contribution (Xun et al., 2007). Lack of alkaline substances in the groundwater system is also helpful in the accumulation of acidity, resulting in a decrease in $\mathrm{pH}$ of the groundwater (Xun et al., 2007).

Ammonia may be present in groundwater as a result of the degradation of naturally occurring organic matter or manmade sources such as nitrogen-fertilizer application, livestock operations, industrial processes, sewage infiltration and cement mortal pipe lining (Wada et al., 2010). High conductivity of well water in the non-agricultural area was possibly due to the location of this area which situated near to coastal area. The addition of salt water from the coastal which is often mixed with groundwater greatly increases the conductivity (Yan et al., 2015).

The well water in the agriculture area has significantly higher turbidity compared to the non-agriculture area. High turbidity in this area was possibly corresponding to rainy season. Turbidity is always typically high during a heavy rain and a storm as a consequence of rapid erosion of surface soils into groundwater (Igboekwe et al., 2011). The groundwater with high TDS concentration is enriched with chloride and the groundwater with low TDS concentration is not or less affected by saline water (Annapoorani et al., 2014). The high TDS recorded in the non-agricultural area indicating the intrusion of salt water.

High salinity of well water in non-agriculture area was possibly due to the location of the non-agriculture area which is near to the coastal area. Other factors such as precipitation, evaporation, mineralogy, type of aquifers and seawater intrusion also may influence the salinity level in the water (Yan et al., 2015).

High level of nitrate in agricultural area in this study was possibly due to extensive use of nitrogen fertilizers and organic matter transported into the groundwater by water percolation from rainfall or from irrigation (Gao et al., 2012). Excessive rainfall also would tend to leach nitrate below the root zone and ultimately to groundwater (Babiker et al., 2004; Hussain et al., 2013). In the non-agriculture area, 35 wells had nitrate values exceeded $10 \mathrm{mg} \mathrm{L}^{-1}$ standard. This possibly due to factors of atmospheric deposition, discharge from septic tanks and leaking sewers which also can contribute to the high concentration of nitrate (Pastén-Zapata et al., 2014). Besides, soil characteristics and hydrogeologic variables such as depth of well, depth below the water table, aggregated thickness of clay above the well screen and thickness of clay in the unsaturated and saturated zones were also considered potential factors influence nitrate contamination in the study area (Yang et al., 2007; Kuo et al., 2007; Khademikia et al., 2013).

High nitrate in shallow well and well of less than 20 years was consistent with the literatures. According to previous studies, nitrate pollution is more common in old and shallow wells (Hu et al., 2005; Rutkoviene et al., 2005). Nitrate contamination generally decreases with increasing depth to the groundwater. A close distance between water table and the land surface in shallow well may cause high concentration of nitrate and a potential sources pf contamination, such as fertilizers and septic system (Rutkoviene et al., 2005; Gao et al., 2012).

Agriculture activities close to well potentially contaminate the groundwater. This is consistent with the finding in this study where high nitrate was determined in the well $<50 \mathrm{~m}$ to the livestock area in the agricultural area. In general, short distance to a point source caused higher nitrate content.

Furthermore, ammonia and nitrate has positive relationship as ammonia can be oxidized to nitrate from nitrogen-fertilizer application. Nitrate concentration in groundwater generally increases with the increasing of ammonia. Nitrate is dissolved inorganic solids and act as conductors in the water while conductivity is the ability of water to conduct an electrical current. Therefore, the presence of nitrate in groundwater can affect the conductivity. Besides, because of nitrate is dissolved inorganic solids, nitrate also has correlation with TDS and salinity (Igboekwe et al., 2011; Annapoorani et al., 2014; Yan et al., 2015).

Nitrate in drinking water may pose a health risk when the levels exceed the MCL of $10 \mathrm{mg} \mathrm{L}^{-1}$ (Coss et al., 2004; Liu et al., 2011). Agriculture uses large amounts of fertilizer and manure compost on farming lands, causing the significant nitrate pollution in groundwater. The hazard quotient assumes there is a level of exposure below which it is unlikely for even sensitive population to 
experience adverse health effects. There may be a concern arising for the potential non-carcinogenic effects if the HQ exceeds $1 \times 10^{-6}$ (Unity).

Elevated nitrate in drinking water have been associated with several adverse health impacts such as diabetes, Agerelated Macular Degeneration (AMD), gastric and thyroid dysfunction (Coss et al., 2004; Kuo et al., 2007; Ruckart et al., 2008; Aschebrook-Kilfoy et al., 2012; Klein et al., 2013).

Previous studies have confirmed that exposure to nitrate is strongly associated with various diseases. For example, infants below 6 months could become seriously ill and may cause fatality due to nitrate exposure. The symptom of nitrate toxic is shortness of breath and blue-baby syndrome (Liu et al., 2011). Besides, long term exposure to low levels of nitrate presents a noncarcinogenic risk to human (Majumdar and Gupta, 2000). Some studies have investigated the relationships between risks of pancreatic and bladder cancers and nitrate exposure caused by drinking water (Ward et al., 2003; Coss et al., 2004). However, no relationship was observed in this study.

\section{Conclusion}

The results of this study show nitrate was higher in the agricultural area compared to the non-agricultural area which exceeds the acceptable level of nitrate in drinking water $\left(10 \mathrm{mg} \mathrm{L}^{-1} \mathrm{NO}_{3}-\mathrm{N}\right)$. This possibly related to the high usage of fertilizer and pesticide. Nitrate also was determined as high in older well, with shallow depth, high turbidity and close by to septic tank and agricultural area. In this study, the possible association between nitrate concentrations and health diseases such as diabetes, goitre and gastric was not significant.

The strength of this study was it managed to compare the nitrate level in the private well waters in two different areas of agricultural and non-agricultural area in Kelantan. This study has considered the physical characteristics of the well in the analysis such as well age and depth which is possible to be associated with high nitrate in the groundwater. The distance of the well to a point source such as agricultural area, septic tank and livestock area were also taken into account in this study. This information is important as predictive factors for nitrate levels in study area.

There are several limitations in this study such as we did not include the geological information in the discussion due to limited data available. This information contribute to the variability in nitrate levels in groundwater and would likely result in substantial misclassification of nitrate exposure (Ismail et al., 2013). Our study is also limited by the fact that we did not have data and evaluate on other contaminants such as pesticides in the well water where the presence of other drinking water contaminants may correlated with high nitrate concentrations. Dietary nitrate intake information such as types of vegetables consumed, the levels of nitrate in the vegetables (including the nitrate content of fertilizers) and the amount of vegetables consumed were not evaluated. Approximately $80 \%$ of dietary nitrate are derived from vegetable consumption. However vegetables contain vitamin $\mathrm{C}$ and other antioxidants that might prevent nitrosamines formation and therefore, is most likely to attenuate association. Besides, the results also cannot be generalized to represent the whole population in the country as the sample was restricted to only certain area in Kelantan.

Future studies should consider widening the sampling area, where the participation of respondents from other states in the country may increase the precision of nitrate exposure. Study also could be improved by increasing the precision of the estimation of the individual's intake of nitrate, through both food and water and controlling for confounding factors such as occupational exposure to chemicals. Additional studies of population with higher exposure level would be also informative. The uses of biomarker such as urine and saliva to confirm the effect of nitrate to human health may be useful.

\section{Acknowledgement}

Utmost gratitude to the laboratory and academic staff of Department of Environmental and Occupational Health, Faculty of Medicine and Health Sciences, University Putra Malaysia (UPM) and East Coast Environmental Research Institute (ESERI), UNISZA for their assist and support. We also acknowledge our gratefulness to the resident of the village for their contribution to the research.

\section{Funding Information}

Ministry of Education Malaysia for the sponsorship (MyPhD).

\section{Author's Contributions}

Aida Soraya Shamsuddin: Designed the study, conducted the survey, interview and data analysis of this study.

Sharifah Norkhadijah Syed Ismail: Designed the study, prepared the manuscript, analyzed and interpreted the data. She also supervised and analyzed the edited manuscript.

Emilia Zainal Abidin: Discussed the results and implications and commented on the manuscript at all stages.

Ho Yu Bin: Discussed the results and implications and commented on the manuscript at all stages.

Hafizan Juahir: Provided the instruments during the data collection. 


\section{Ethics}

Universiti Putra Malaysia/Ethics Committee for Research Involving Human Subjects (JKEUPM).

\section{References}

Almasri, M.N., 2007. Nitrate contamination of groundwater: A conceptual management framework. Environ. Impact Assess. Rev., 27: 220-242. DOI: 10.1016/j.eiar.2006.11.002

Annapoorani, A., A. Murugesan, A. Ramu and N.G. Renganathan, 2014. Hydrochemistry of groundwater in and around Chennai, India-A case study. Res. J. Chem. Sci., 4: 99-106.

Aschebrook-Kilfoy, B., S.L. Heltshe, J.R. Nuckols, M.M. Sabra and A.R. Shuldiner et al., 2012. Modeled nitrate levels in well water supplies and prevalence of abnormal thyroid conditions among the old order Amish in Pennsylvania. Environ. Health. DOI: 10.1186/1476-069X-11-6

Babiker, I.S., M.A.A. Mohamed, H. Terao, K. Kato and K. Ohta, 2004. Assessment of groundwater contamination by nitrate leaching from intensive vegetable cultivation using geographical information system. Environ. Int., 29: 1009-1017.

DOI: $10.1016 / \mathrm{S} 0160-4120(03) 00095-3$

Jordan, C. and R.V. Smith, 2005. Methods to predict the agricultural contribution to catchment nitrate loads: Designation of nitrate vulnerable zones in Northern Ireland. J. Hydrol., 304: 316-329. DOI: $10.1016 /$ j.jhydrol.2004.07.037

Chang, C.C., S.S. Tsai, T.N. Wu and C.Y. Yang, 2010. Nitrates in municipal drinking water and nonHodgkin lymphoma: An ecological cancer casecontrol study in Taiwan. J. Toxicol. Environ. Health A, 73: 330-338. PMID: 20077301

Chowdary, V.M., N.H. Rao and P.B.S. Sarma, 2005. Decision support framework for assessment of nonpoint-source pollution of groundwater in large irrigation projects. Agric. Water Manage., 75: 194-225. DOI: $10.1016 /$ j.agwat.2004.12.013

Coss, A., K.P. Cantor, J.S. Reif, C.F. Lynch and M.H. Ward, 2004. Pancreatic cancer and drinking water and dietary sources of nitrate and nitrite. Am. J. Epidemiol., 159: 693-701. PMID: 15033647

Dunn, S.M., A.J.A. Vinten, A. Lilly, J. DeGroote and M. McGechan, 2005. Modelling nitrate losses from agricultural activities on a national scale. Water Sci. Technol., 51: 319-327. PMID: 15850205

Gao, H., M. Matyka, B. Liu, A. Khalili and J.E. Kostka et al., 2012. Intensive and extensive nitrogen loss from intertidal permeable sediments of the Wadden Sea. Limnol. Oceanogr, 57: 185-198. DOI: 10.4319/lo.2012.57.1.0185
Gupta, S.K., R.C. Gupta, S.K. Chhabra, S. Eskiocak and A.B. Gupta et al., 2008. Health issues related to $\mathrm{N}$ pollution in water and air. Ind. Agric. Environ. Health, 94: 1469-1477.

Hu, K., Y. Huang, H. Li, B. Li and D. Chen et al., 2005. Spatial variability of shallow groundwater level, electrical conductivity and nitrate concentration and risk assessment of nitrate contamination in North China Plain. Environ. Int., 31: 896-903.

DOI: 10.1016/j.envint.2005.05.02

Hussain, H., M.K. Yusoff, M.F. Ramli, P. Abd Latif and H. Juahir et al., 2013. Temporal patterns and source apportionment of nitrate-nitrogen leaching in a paddy field at Kelantan, Malaysia. Pak. J. Biological Sci., 16: 1524-1530. PMID: 24511695

Igboekwe, M.U., A.O. Akankpo and I.E. Udoinyang, 2011. Hydrochemical evaluation of groundwater quality in Michael Okpara University of Agriculture, umudike and its environs, southeastern Nigeria. J. Water Resource Protect., 03: 925-929. DOI: $10.4236 /$ jwarp.2011.312103

Ismail, S.N.S., R. Firuz and Y. Ismail, 2013. Groundwater vulnerability mapping: DRASTIC versus simplified overlay version. Scottish J. Arts, Social Sci. Scientific Studies, 11: 104-125.

Kamaludin, M., K.A. Rahim and A. Radam, 2013. Assessing consumer's willingness to pay for improved domestic water services in Kelantan, Malaysia. Int. J. Soc. Sci., 8: 45-53.

Khademikia, S., Z. Rafiee, M.M. Amin, P. Poursafa and M. Mansourian et al., 2013. Association of nitrate, nitrite and Total Organic Carbon (TOC) in drinking water and gastrointestinal disease. J. Environ. Public Health. DOI: 10.1155/2013/603468

Klein, B.E.K., J.A. McElroy, R. Klein, K.P. Howard and K.E. Lee, 2013. Nitrate-nitrogen levels in rural drinking water: Is there an association with agerelated macular degeneration? J. Environ. Sci. Health. Part A, Toxic Hazard. Subst. Environ. Eng., 48: 1757-1763. DOI: 10.1080/10934529.2013.823323

Kuo, H.W., T.N. Wu and C.Y. Yang, 2007. Nitrates in drinking water and risk of death from rectal cancer in Taiwan. J. Toxicol. Environ. Health, Part A, 70: 1717-1722. DOI: 10.1080/15287390701457704

Liu, A., J. Ming and R.O. Ankumah, 2005. Nitrate contamination in private wells in rural Alabama, United States. Sci. Total Environ., 346: 112-120. DOI: $10.1016 /$ j.scitotenv.2004.11.019

Liu, C.W., C.N. Lin, C.S. Jang, M.P. Ling and J.W. Tsai, 2011. Assessing nitrate contamination and its potential health risk to Kinmen residents. Environ. Geochemistry Health, 33: 503-514. DOI: $10.1007 / \mathrm{s} 10653-010-9367-\mathrm{x}$

Majumdar, D. and N. Gupta, 2000. Nitrate pollution of groundwater and associated human health disorder. Ind. J. Environ. Health, 2: 28-39. 
Manassaram, D.M., L.C. Backer and D.M. Moll, 2006. A review of nitrates in drinking water: Maternal exposure and adverse reproductive and developmental outcomes. Environ. Health Perspectives, 114: 320-327. PMID: 16507452

Zawawi, M.A.M., M.K. Yusoff, H. Hussain and S. Nasir, 2010. Nitrate-nitrogen concentration variation in groundwater in a paddy field. J. Institution Eng. Malaysia, 71: 1-9.

Pastén-Zapata, E., R. Ledesma-Ruiz, T. Harter, A.I. Ramírez and J. Mahlknecht, 2014. Assessment of sources and fate of nitrate in shallow groundwater of an agricultural area by using a multi-tracer approach. Sci. Total Environ., 470-471: 855-864. DOI: $10.1016 /$ j.scitotenv.2013.10.043

Ruckart, P.Z., A.K. Henderson, M.L. Black and W.D. Flanders, 2008. Are nitrate levels in groundwater stable over time? J. Exposure Sci. Environ. Epidemiol., 18: 129-133. DOI: $10.1038 /$ sj.jes.7500561

Rutkoviene, V., A. Kusta and L. Eesoniene, 2005. Evaluation of the impact of anthropogenic factors on the pollution of shallow well water. Ekologija, 4: 13-19.

Wada, Y., L.P.H. van Beek, C.M. van Kempen, J.W.T.M. Reckman and S. Vasak et al., 2010. Global depletion of groundwater resources. Geophys. Res. Lett. DOI: 10.1029/2010GL044571
Ward, M.H., K.P. Cantor, D. Riley, S. Merkle and C.F. Lynch, 2003. Nitrate in public water supplies and risk of bladder cancer. Epidemiology, 14: 183-190. DOI: 10.1097/01.EDE.0000050664.28048.DF

Ward, M.H., T.M. DeKok, P. Levallois, J. Brender and G. Gulis et al., 2005. Workgroup report: Drinking-water nitrate and health-recent findings and research needs. Environ. Health Perspectives, 113: 1607-1614. PMID: 16263519

Xun, Z., Z. Hua, Z. Liang, S. Ye and Y. Xia et al., 2007. Some factors affecting TDS and $\mathrm{pH}$ values in groundwater of the Beihai coastal area in Southern Guangxi, China. Environ. Geol., 53: 317-323. DOI: $10.1007 / \mathrm{s} 00254-007-0647-4$

Yan, S., S. Yu, Y. Wu, D. Pan and D. She et al., 2015. Seasonal variation in groundwater level and salinity in coastal plain of Eastern China influenced by climate. J. Chem. DOI: 10.1155/2015/905190

Yang, C.Y., D.C. Wu and C.C. Chang, 2007. Nitrate in drinking water and risk of death from colon cancer in Taiwan. Environ. Int., 33: 649-653. DOI: 10.1016/j.envint.2007.01.009 